\title{
Consolidation and Legacy of Foreign Currency Household Lending in Central and Eastern \\ Europe: The Case of Hungary
}

ABSTRACT

During the first decade of the 21st century, household FX loans spread in numerous countries in Central and Eastern Europe, where they caused serious macroeconomic and social problems with the spillover of the global financial crisis. Disregarding countries that joined the euro area, Hungary was the only state where household FX loans were completely phased out. The aim of the paper is to provide a structured presentation of the circumstances of the FX loan conversion in Hungary and to assess the potential risks related to the post FX loan period. The paper reviews the relevant international literature about the causes and the impact of unsecured FX lending in the household sector and analyses the phasing-out of the household FX loans in Hungary from the point of view of the legal considerations, the interest rate environment, the macroeconomic stability, the elbowroom in FX reserves and the timing of the process. The paper concludes that the conversion happened at the first date which was legally allowed and economically properly underpinned. The paper also presents that the central bank reacted to the new challenges of the phasing-out process with new macroprudential tools to prevent excessive indebtedness and over-lending, to reduce households' interest rate risks, and to ensure that customers have appropriate income reserves, in order to improve the quality and sustainability of lending to households in the future.

KEY WORDS: $\quad$ mortgage loans, financial stability, monetary policy, debt consolidation, conversion, CEE, macroprudential policy

JEL Classification: E58, E65, G21.

'Economy and Competitiveness Research Institute, National University of Public Service, and MNB Institute, Corvinus University of Budapest, Budapest, Hungary

2Public Finance Research Institute, National University of Public Service, Budapest; Honorary University Professor, Szent István

\section{Introduction}

Borrowing above one's creditworthiness, over-indebtedness and the resulting debt trap have been among the most serious recurring fundamental problems in the world economy since the 1970s. Relative to global gross domestic product (GDP), a massive increase is seen in debts, which was given fresh momentum in the decade after the turn of the millennium. In the case of emerging countries, the problems arising from the general indebtedness was further increased by the

Correspondence concerning this article should be addressed to: Pál Péter Kolozsi, 1118 Budapest, Ménesi út 5. ÁKK Kollégiumi épület 510A, Hungary. E-mail: kolozsi.pal.peter@uni-nke.hu high level of indebtedness in foreign currency to foreign investors, as when the domestic currency weakens, even if debts stagnate, debt service increases and becomes practically non- financeable (concerning the impacts of the presence in residents' portfolio of foreign currency assets and liabilities see: Basso, CalvoGonzalez, \& Jurgilas, 2007; Basso, Calvo-Gonzalez, \& Jurgilas, 2011; Brown \& De Haas, 2012; Brown, De Haas, \& Sokolov, 2013).

Household lending in FX, which is in the focus of this paper, spread in numerous Central and Eastern European states already in the early 2000s (concerning the performance of the Central European Banking Industry see: Jackowicz, Kowalewski, \& Kozłowski, 
2011). This paper tackles households' foreign currency loans in the Central and Eastern European Region, from introduction and fast growth to consolidation and phasing-out, including the challenges that followed that period and the regulatory responses given to them. Being a case study, this paper describes the example of Hungary, a country significantly affected by the foreign currency lending problem, and the only one in the region that completely phased out these loans of the household sector.

\section{Spread Of Household Foreign Currency Loans In Central And Eastern Europe}

In Central and Eastern Europe, households' loans granted in FX spread in the 2000s. According to Csajbók, Hudecz and Tamási (2010), at the end of that decade in Estonia and Latvia the FX shares in household debt was 80-90 percent, in Lithuania, Hungary and Romania around 50 percent, while in Poland and Bulgaria less than 40 percent. In the Czech Republic and Slovakia household FX borrowing was quasi non-existent (concerning the determinants of foreign currency loans see: Cuaresma, Fidrmuc, \& Hake, 2011; Eichengreen \& Hausmann, 2010; Jeanne, 2003; Ranciere, Tornell, \& Vamvakidis, 2010; Zettelmeyer, Nagy, \& Jeffrey, 2010).

Geographically, the individual countries were affected to various extents:

- Due to the resolute supervisory and regulatory action, and partly to the relatively low interest margins, in Slovakia, Slovenia and the Czech Republic, household foreign currency lending practically did not spread, or accession to the euro area eliminated the problem.

- In the Baltic states (Estonia, Latvia and Lithuania), foreign currency lending had already been characteristic before 2000, and loans were primarily denominated in euro, meaning that the adoption of the euro solved this problem.

- In Poland, Hungary and Romania, household foreign currency lending evolved into a considerable risk in the first half of the 2000s. All in all, euro-based lending was the most wide-spread in the region, but in Poland and Hungary, loans denominated in Swiss franc were more typical.

- Household foreign currency lending spread in
Bulgaria, but as the country adopted a currency board regime, the exchange rate of the Bulgarian currency vis-à-vis the euro was fix, then Bulgaria was not facing any macroeconomic problem from that point of view.

Taking into consideration of the impact of these FX loans on the balance sheet of the banking sector and the households, the affected countries may be divided into two groups.

(1) In certain countries foreign currency items appeared on both the asset side (credit) and the liability side (deposit) of the banking sector.

(2) In other countries a significant part of loans was denominated in foreign currency, but deposits were still made in local currency, meaning that the open balance sheet position of banks was hedged by off-balance sheet items.

According to Geng, Scutaru and Wiegand (2018) these are two fundamentally different situations with disparate causes and consequences. In the case of group (1), the phenomenon can practically be considered as a deposit-driven euroization. A high deposit portfolio in foreign currency accumulated due to distrust in the local economy and local currency, with the consequence that banks granted foreign currency loans in order to reduce or close their FX position. In contrast, in the case of group (2), no foreign currency deposits are seen on the liability side of banking books, and households typically accumulated deposits in local currency. In this case, foreign currency loans put households in a kind of speculative FX position, enabling them to make a temporary profit of the margin between the local and the foreign currency interest rates, as they were typically paid higher interests on their deposits than the cost of their loans, with the accentuated presumption that the exchange rate would not devalue ("carry-trade euroization"). In this situation, banks get into an open foreign currency position, which requires hedging and thus represents a substantial risk to financial stability (concerning the carry trade behaviour of households and the euroization of bank deposits in Eastern Europe see: Beer, Ongena, \& Peter, 2010; Brown \& Stix, 2015; De Nicoló, Honohan, \& Ize, 2005).

Lending in foreign currency with simultaneous accumulation of foreign currency deposits characterized countries where - for some reason - confidence in the local currency dropped considerably. In the Central and Eastern European Region, causes included, for 
Table 1. Household FX debt/GDP in certain countries of the Central and Eastern European Region at the end of 2010

\begin{tabular}{lcc}
\hline Household FX debt/GDP & Deposit-driven euroization & Carry-trade euroization \\
\hline more than 20 per cent & Croatia, Latvia & Hungary, Lithuania, Estonia \\
$10-20$ per cent & Romania, Poland \\
5 -10 per cent & Bulgaria & \\
less than 5 per cent & & Slovakia, Czech Republic \\
\hline
\end{tabular}

example, former experiences of hyperinflation in the period of transition from a socialist to a market economy, faced by both households and the business sector, which resulted in the fast devaluation of savings. This was the case among others in Croatia, Bulgaria and, to some extent, in Latvia. This kind of euroization can be extremely difficult to handle, as households act on their personal adverse experiences, and a fundamental change is required in their own personal perception. It is not a simple coincidence that in this country group, the challenges related to household foreign currency lending were in most cases brought to an end by a complete giving up of the monetary policy independence and accession to the euro area.

Foreign currency lending based on carry-trade was characteristic in Hungary, Romania and Slovenia, while in the Baltic region, Lithuania and Estonia. What needs to be changed during the management of such cases is not the lack of confidence in the local currency on the part of households and the business sector, as there is no crisis of confidence. Rather, economic policy and regulatory actions need to be taken to prevent the affected economic sectors, essentially households from taking risky and speculative open FX positions with their loan transactions.

\section{Unsecured Household Foreign Cur- rency Lending As A Systemic Risk Fac- tor}

There are several factors that may facilitate indebtedness in foreign currency among households, but according to Kolozsi, Banai and Vonnák (2015) the following were the most relevant in the affected Central and Eastern European countries:

- lax fiscal policy, high sovereign debt and high risk premium with high inflation, which resulted in high nominal interest rates relative to those in developed economies;

- due to the relatively underdeveloped financial and securities markets, schemes with low premiums or fixed interest rates are unavailable;

- in addition to the interest margin, economic stakeholders underestimated the exchange rate risk involved in foreign currency lending, especially if the exchange rate was relatively stable in a given period;

- lower foreign currency interest rates resulted in higher borrowing caps, the assessment of the borrower's creditworthiness "virtually" improved;

- moral hazard phenomenon (see the model by Schneider \& Tornell, 2004);

- expecting a relatively fast adoption of the euro;

- risk-based competition in the banking sector, i.e. the pretension and desire to obtain larger market shares frequently resulted in excessive risk taking by banks;

- desire for "fast enrichment", characteristic of certain social groups, and the related "promise of convergence", lax and deficient regulation, and the low level of financial literacy as institutional inadequacies.

Even if reasonable explanations can be given for household indebtedness in foreign currency (see Ize, 2005), it may carry significant risks in the case of households. To a major extent this arises from the 
fact that the majority of borrowers choose indebtedness in a foreign currency exactly because they can borrow larger amounts than in local currency. Thus they are not prepared for the adverse impacts of the long-term increase in exchange rate volatility, and foreign currency lending essentially "facilitates" over-indebtedness.

However, it is important to underline that the relationship evolving in lending is fundamentally market-based. Demand arises from potential borrowers, and banks grant loans. Credit market includes banks representing supply, and households with other borrowers, representing - increasing - demand. The state has options: regulating and controlling loan supply and the process of lending through its authorities, or interfering with market developments to a very slight extent or not at all. Responsibility for such a "non-interference", and moreover, for a lenient toleration of "maverick" banking practices also lies with the state. This means that the government is accountable both for regulation and the lack of regulation. In addition to the government's responsibility for regulation and control, banks and, on the demand side, households that have taken loans and have assumed redemption above their reasonably expected income expectations also share liability. Thus there is a tripartite accountability for the evolution of the household debt problem (for further details see: Kolozsi, Lentner, \& Tóth, 2010), but it is also true that the relative answerability of those in a borrowing position is lower, as they are less capable of having a comprehensive view concerning the functioning of the financial system and have a moderate financial and banking knowledge, while higher responsibility should be assigned to state authorities for their "lenient conduct" and to banks for their aggressive loan expansion and inappropriate communication.

The responsibility issue is even more relevant as FX lending has a significant subprime characteristic, with creditors easing households' liquidity constraints by several means, which at the same time meant considerable subprime lending as well (Bethlendi, 2015). It means that a considerable part of the borrowing households was at least partly uncreditworthy - simply because there is no technical solution for restoring the creditworthiness of credit-impaired customers through changing the currency of lending. This discrepancy was "successfully" bridged by loan brokers' massive campaigns, use of obsolete credit solvency indicators, "leniency" of banks, customers' superficial judgment of their own solvency, and governments - being interested in the temporary enrichment of banks and their customers - refusing to regulate the market of FX loans.

It has to be taken into consideration that households' financial literacy could not be considered as developed (Kolozsi et al., 2015). The euro, and even more the Swiss Franc was considered as a safe-haven currency, and as banks failed to raise awareness and due to households' eagerness to borrow, foreign currency lending became endemic. Although FX loans were granted for 10-30 years, but the banks did not have sufficient FX funds to cover them for that maturity, making consequently that these loan positions continuously demanded hedging (typically involving renewal risk in the short-term foreign currency swap market).

Bethlendi (2011) analysed changes in the regulation of 12 Central and Eastern European countries (Bulgaria, the Czech Republic, Estonia, Croatia, Hungary, Latvia, Lithuania, Poland, Romania, Serbia, Slovakia and Slovenia) in the years preceding the crisis. The paper concludes that half of the analysed states adopted measures, managed to limit the spread of foreign currency lending and prevent them from gaining preponderance. The Czech Republic and Slovakia managed to completely avoid this trend, most essentially thanks to their stable macroeconomic environment and highly developed and improving domestic property financing market. Bulgaria used administrative measures to keep the ratio of foreign currency lending low, and Croatia was also successful in reducing this ratio. The example of Slovenia shows that not even the adoption of the euro was sufficient to completely manage the problems encountered as a result of foreign currency lending, and the example of Poland illustrates that monetary policy means (primarily easing monetary policy conditions) are also suitable for checking the spread of loans denominated in foreign currency. The actions taken in Estonia, Latvia, Lithuania, Romania and Serbia basically failed to bring the expected result, and so the ratio of foreign currency loans increased considerably. However, Hungary does not fit 
even this group, as uniquely in the region, before the crisis the Hungarian authorities did not take any notable action whatsoever to prevent the indebtedness of households in foreign currency, thus assuming a huge exchange rate risk. Bethlendi (2011) concluded that the international examples clearly evidence that the "we cannot do anything" approach, especially characteristic of Hungary, was more harmful than the "let us try to do something despite the difficulties" attitude.

\section{Phasing Out Household For- eign Currency Loans - The Case Of Hungary}

The economic crisis considerably changed foreign currency lending, as the high volatility and the weakening of local currencies in the emerging region showed the downsides of these loans, otherwise favourable in terms of the interest rates. The impact of the crisis was different and depended on the characteristics of the loans and the regulatory environment. In countries where a significant portion of loans were real variable-rate FX loans - Po- land, Romania and the Baltic states - the decreased interest rate more or less counterbalanced the negative FX impact, therefore the increase in monthly instalment was limited. In Hungary however both repayment instalments and principal debts increased considerably while real property collateral devalued - the explanation is that in Hungary the features of the FX loan products were unfair, so debtors were exposed to an interest rate shock in addition to the exchange rate shock (Bethlendi, 2015). It is because of these factors that Hungary was hit especially hard by the consequences of the crisis, and the ratio of defaulting debtors and nonperforming loans rose to levels close to causing a financial stability problem.

The elbowroom of monetary policy considerably decreased, and exchange rate sensitivity was especially high in the economy, and as a result, instead of inflationary developments, the interest rate policy was compelled to focus more and more on the increasingly volatile exchange rate movements and their impact on financial stability. As the problems encountered in the banking system and by house-

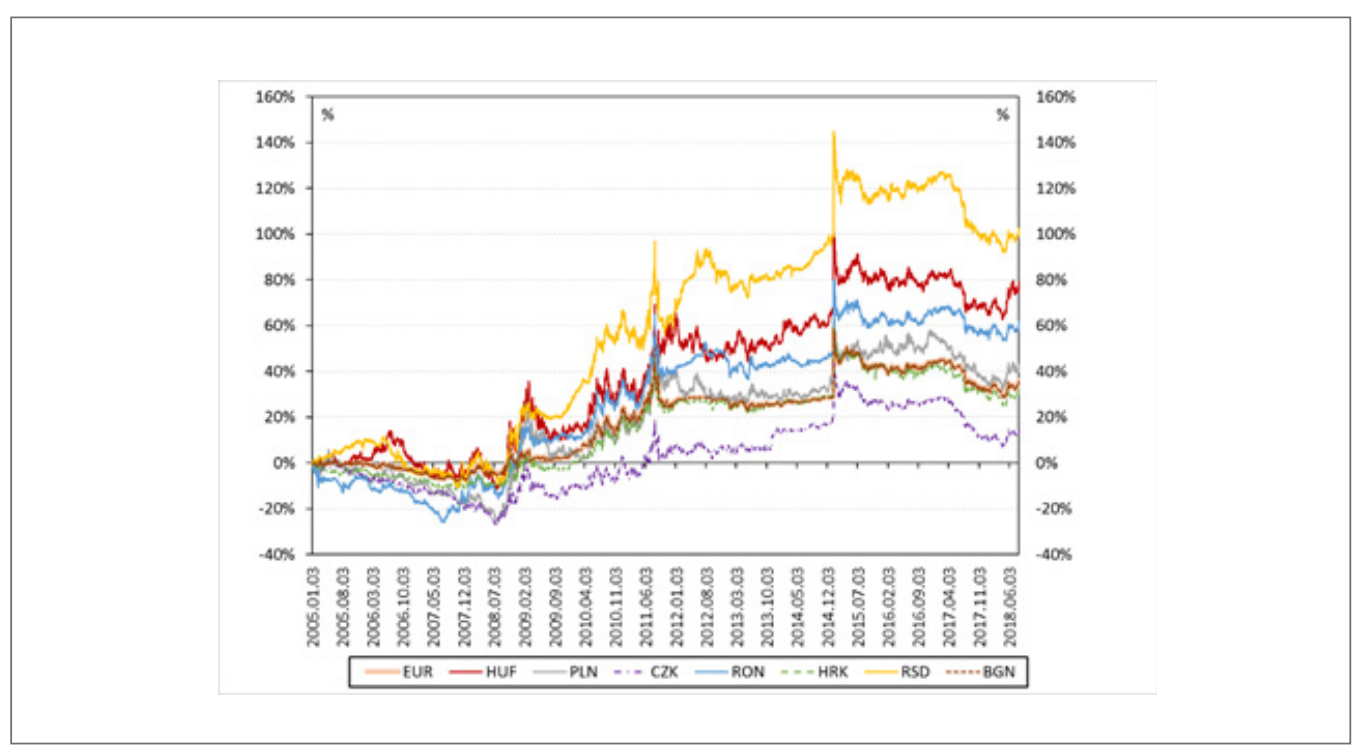

Figure 1. Exchange rates of certain CEE currencies to CHF. 
holds - with other stakeholders also heavily indebted in FX as central and local government and SMEs - carried potentially the menace of putting the government under serious financial pressure over time about the solvency of the country, ultimately the state had to consider seriously the increasing risks arising from foreign currency loans.

Hungary's example is a clear rendering of the significant macroeconomic and social harm caused by the materialization of the risks involved in household foreign currency lending. As the overwhelming majority of households have revenues in the local currency (forint, HUF) and a limited capacity to manage exchange rate risks, developments in the exchange rate had a particular significance. In March 2009 and in the second half of 2011, the HUF fell considerably against the EUR, and in addition, in summer 2010, the previously fairly stable EUR-CHF exchange rate started to make a considerable shift (Figure 1). The forint devalued against the Swiss franc by 60-70 per cent between 2008 and 2011, and this hit Hungarian borrowers especially hard, as foreign currency loans were overwhelmingly denominated in CHF.

According to Dancsik et al. (2015) in nearly all countries of Central and Eastern Europe, responses to the crisis included some kind of an "action package" related to foreign currency loans. In addition to Slovenia and the Baltic states, which adopted the euro, initiatives have been taken to handle the problem of household foreign currency loans in several countries in the region (in addition to Hungary especially in Poland and in Croatia, where court decisions might lead to the reassessment of household FX loan agreements), but to date Hungary has been the only country of the region to completely phase out foreign currency loans. For this reason, Hungary's example is described as a scheme that might be followed by other states currently facing the problems posed by foreign currency lending.

By the autumn of 2008, the debts of households, the government and local governments had become unmanageable (on the creditworthiness of municipal enterprises, see: Zéman, Hegedus, \& Molnar, 2018), due partly to the high amount of debts, and partly to their denomination in foreign currency. In the period following the political changes in 2010 , policy actions were focused on fending off the collapse of the central budget and then that of the social security system. Fiscal consolidation had been completed by 2013, and Hungary was released from the European Union's Excessive Deficit Procedure, started in 2004 (the EDP had been applied to Hungary from the beginning of the Hungarian membership in the EU).

The crisis management actions taken after the feed-through of the crisis proved to be unsuccessful in finding a final solution for foreign currency lending to households. The complete phasing-out of household loans denominated in or based on foreign currency, started in the autumn of 2014. Based on the following assessment, FX loans were converted into HUF at the first date legally allowed and economically properly underpinned (Kolozsi et al., 2015).

\subsection{Legal Considerations}

In Hungary the comprehensive government action related to household foreign currency loans were preceded by the clarification of legal aspects. This was done by the legislative alignment resolution of the Curia - the highest judicial authority in Hungary - promulgated in June 2014. The Curia's decision subsequently served as a guidance for the courts and for the legislator. For more on judicial legislation, see: Kecskés (2015).

The consequence of the Curia's decision was that banks must settle accounts with any overcharges paid by customers due to unilateral increases in the interest rates and charges and to the application of the exchange rate margin as a charge, however, it was also made clear that conversion can be allowed at the current market rate.

In September 2014, the National Assembly passed Act XXXVIII of 2014, which stipulated that overcharges to debtors must be taken into consideration as principal prepayment with retroactive effect in all all consumer FX mortgage loans, not included subsidised loans, granted after 1 May 2004 and not cancelled before 26 July 2009. In addition, the "fair banking" regulation was also adopted which requires the application of fixed or referencebased interests on all consumer loans ("transparent pricing" principle). 
Table 1. Main Propositions in the Curia's 2014 Legislative Alignment Resolution

Exchange rate risk Unilateral interest rate hikes Exchange rate margin

Allocating the exchange rate risk to debtors is unfair if the exchange rate risk specified in the contract is incomprehensible for the average debtor, and in this case the contract may be declared null and void.
A unilateral interest rate hike is unfair and unlawful if the impact of the individual conditions on payment liabilities is unclear and not transparent for the debtor.
The application of the exchange rate margin as a charge is unfair and void in every case and under any circumstances.

\subsection{Interest Rate Environment And Macroeconomic Stability}

The Central Bank of Hungary (MNB) started to cut the interest rates in 2012 which was a precondition to the conversion of foreign currency loans to forint loans. By the summer of 2014, the base rate had fallen from 7 to 2.1 per cent, thus preventing the conversion from causing a sharp rise in the interest rates and the monthly instalments.

In order to phase out household foreign currency loans smoothly, Hungary's macroeconomic stability had to be raised to a level where phasing-out could be implemented without any major risks. This was granted by the consolidation of the central budget, the reduction of sovereign debt carried out after 2010, the simultaneous achievement of equilibrium and growth and the monetary policy turnaround launched in 2013 (see: Matolcsy, 2015; Matolcsy \& Palotai, 2018).

\subsection{Elbowroom in Foreign Currency Reserves}

The phasing-out of foreign currency loans triggers demand for foreign currency liquidity on the banks' part, which could have put the HUF exchange rate under considerable pressure. For this reason, as an indispensable precondition of a well-organized conversion of foreign currency loans to forint loans, the MNB had to dispose the amount of foreign currency required for the hedging transactions of banks and to be able to give banks access to that FX liquidity. The central bank had to have the required elbowroom in foreign currency reserves, i.e. FX reserves had to exceed the short-term external debt, being the most important indicator determin- ing the optimum level of FX reserves (see: Csávás \& Csom-Bíró, 2017). By 2014, the MNB’s reserve adequacy had reached the level that enabled the safe conversion of the FX loans, with a view to the fact that as a result of a ban on granting foreign currency loans, early final prepayment and the repayment of the outstanding loans (amortization), the amount of FX mortgage loans waiting for conversion had fallen to EUR 9 billion from the previous EUR 19 billion peak.

\subsection{Conversion Programme of the Central Bank}

At the end of September 2014, the portfolio of consumer mortgage loans denominated in or based on foreign currency amounted to HUF 3350 billion (EUR 10.8 billion), which decreased by more than HUF 500 billion (EUR 1.7 billion) after the settlements emerging from the Curia's legislative alignment resolution. This means that the conversion of foreign currency mortgage loans affected a portfolio of EUR 9 billion. However, an impairment of EUR 1.56 billion (HUF 480 billion) had already been initiated for the above-mentioned loan portfolio, from which -according to the MNB's calculations - EUR 0.4-0.6 billion (HUF 120-180 billion) had probably been released. Consequently, banks' hedging demand related to the conversion of foreign currency loans may have been around EUR 8 billion. Thus, the EUR 7.83 billion allocated at the MNB's tenders means that banks nearly completely hedged their conversion via the instruments of the central bank.

The MNB's programme was designed to hedge banks' foreign currency demand without jeopardiz- 


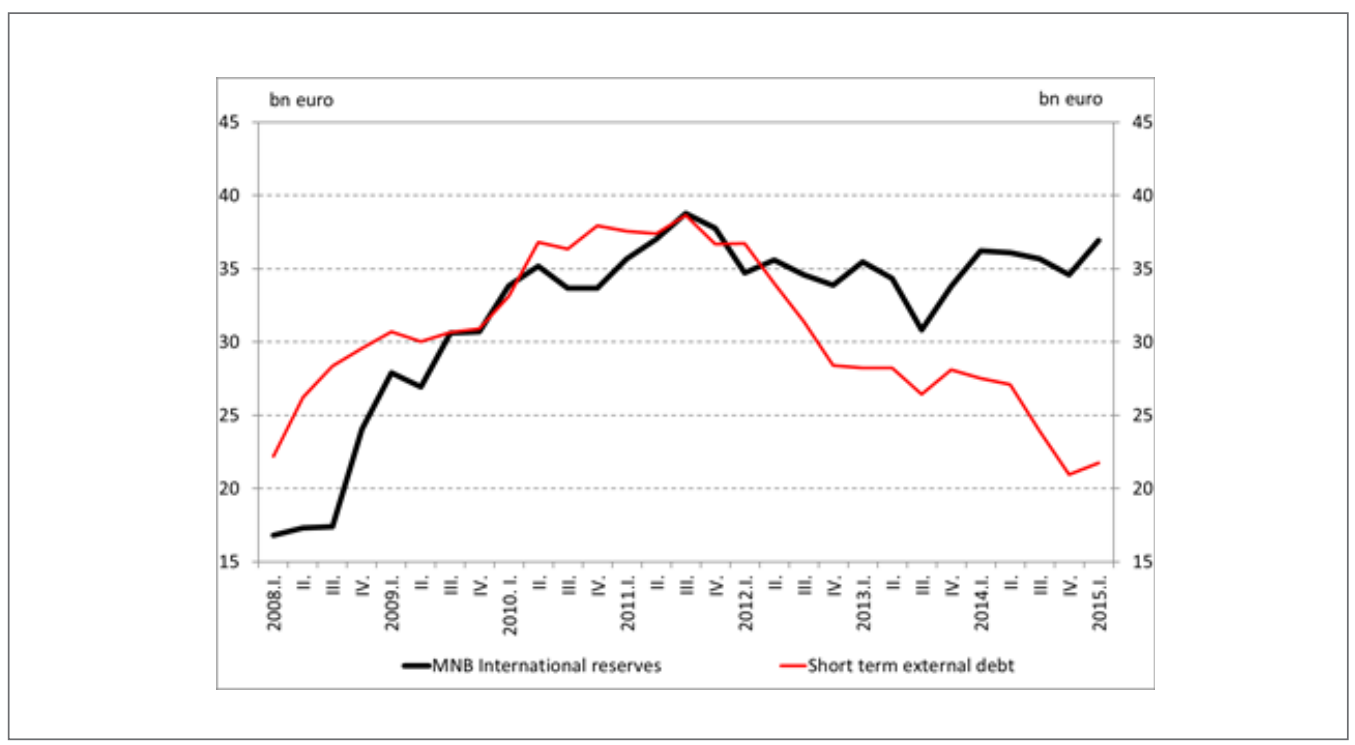

Figure 2. MNB's foreign currency reserve and the short term external debt.

ing the optimum level of the central bank's reserve even if the banking limits are completely used. With preference to conservative provisioning, the Guidotti-Greenspan rule is guiding: in 2015 Q1, the foreign currency reserve amounted to EUR 37 billion, while the short-term external debt, on a constant decrease since 2011, was EUR 22 billion at the same time. The reserve adequacy was guaranteed by the fact that the FX liquidity provided by the central bank moderated the external debt and consequently, the central bank's demand for foreign currency reserves, and through the proper dispersion and gradual use of FX reserves in 2014-2017, these assets also covered the amount of foreign currency that banks required for the conversion of FX loans to forint loans.

Concerning the banking accounts of the households, the formal conversion of foreign currency loans to forint loans took place in the spring of 2015. Through euro purchases, commercial banks hedged their exchange rate risks arising from the conversion, an action indispensable for prudent bank operation. Banks were required to convert foreign currency loans to forint loans at the more favourable for the borrower between the two fol- lowing rates: the official daily MNB exchange rate valid on 7 November 2014 or the most favourable exchange rate for the borrower applied in the period since the 16 June 2014 adoption of the Curia's decision. Based on these considerations, the exchange rate was set at HUF 308.97 for the euro and HUF 256.6 for the Swiss franc, meaning that at the time of the phasing-out, the exchange rates were higher (HUF was weaker) than between 2002 and 2008. As in addition to rescuing households from the trap of foreign currency loans, a simultaneous and inevitable purpose of the government and of the central bank was to restore a consolidated financial position for the banks, the Hungarian public authorities had to carry out a complex consolidation process underpinned by the fair bank act and the mandatory compensation of the damages caused by banks' unjustified unilateral contract amendments.

As an integral outgrowth of the procedure launched in the autumn of 2014, the households' foreign currency loans remaining after the conversion of mortgages were eliminated in 2015. The borrowers of car and personal loans indebted in foreign currency (representing app. 250000 contracts) were handled by the decision made by the 


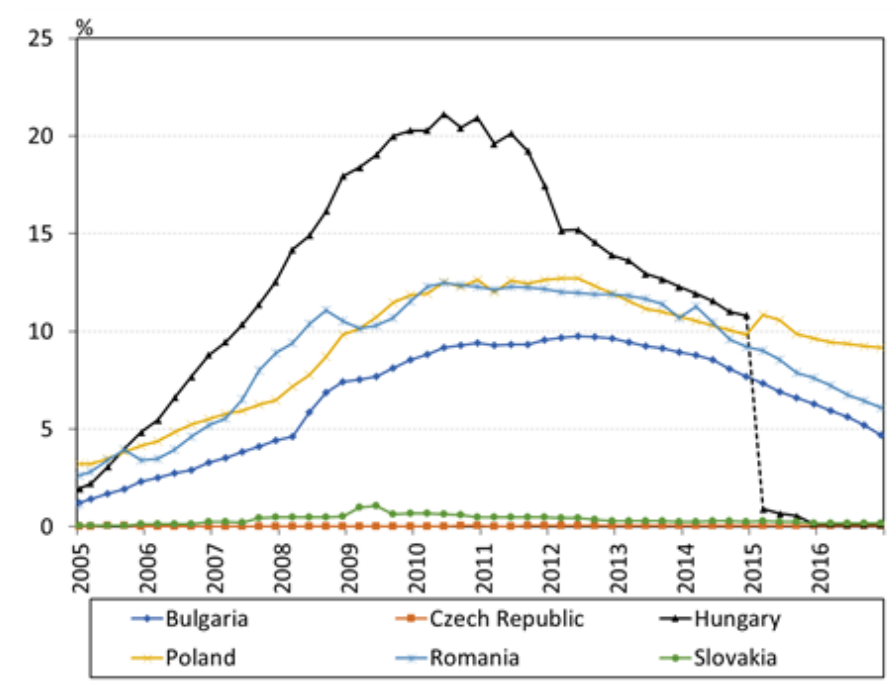

Figure 3. Ratio of household foreign currency loans to GDP in certain countries of the Central and Eastern European Region.

MNB and the government in the summer of 2015. The MNB organized the related tenders in August and September 2015. During these tenders the central bank sold CHF 650 million to banks, thus practically completely cleaned the financial system of household FX loans - a financial product that had carried a very high risk concerning the exchange rate and consequently social stability.

\subsection{Timing}

On 15 January 2015, the Swiss National Bank unpegged the Swiss franc vis-à-vis the Euro, abandoning protection against exchange rate fluctuations. The global financial and capital markets responded with significant exchange rate movements. Within a few minutes, the Swiss franc soared from 1.2 to 0.8052 to the euro, and rocketing from the HUF250-260 to almost HUF 380. Thus the abandonment of the peg strengthened the Swiss Franc, weakened the Euro and considerably hit the Forint, which could have had serious consequences for the households indebted in Swiss franc if consolidation had not been performed a few months earlier. The abandonment of the Swiss exchange rate cap would have hit the Hungarian lending market hard if the approximately CHF 20 billion exposure had still been in place (including business loans denominated in foreign currency). As however, the government and the central bank had eliminated the exposure of households, local governments and some part of the corporate sector (essentially SMEs), the majority of the stakeholders were no longer affected by the decision of the swiss central bank. Hungarian authorities had made conscious efforts at reducing the exposure of public finances, businesses and households to foreign currency.

The phasing-out of household foreign currency loans stabilized Hungarian families' financial position: the net worth and disposable income of a household are no longer affected by exchange rate fluctuations, the burden of repayment has reduced, and this can improve also consumer and investment dynamics. In addition, it had a favourable impact on the stability of the banking system, as credit risk considerably decreased and banks' loan portfolios significantly improved. Strengthening the banking system reduces Hungary's sovereign risk, which in turn, lowers interest rates and boosts economic activity. 


\section{Challenges to Financial Stability after the Phasing-out of Household Foreign Currency Loans}

The crisis shed light on the significance of responsible lending. The purpose of the related regulations is the early identification and prevention of risks, in addition to strengthening international cooperation. The purpose of the changing requirements is to prevent excessive indebtedness and over-lending, to reduce households' interest rate risks and to ensure that the customers more exposed to interest rate risks have appropriate income reserves, in order to improve the quality and sustainability of lending to households in the future.

One of the typical actions was the creation of macroprudential powers, as during the crisis microprudential interventions responding to case-by-case banking problems and risks were insufficient to prevent systemic financial disorders (about the effectiveness and transmission of macroprudential tools see: Akinci \& Olmstead-Rumsey, 2018; Boar, Gambacorta, Lombardo, \& Pereira da Silva, 2017; Carreras, Davis, \& Piggott, 2016; Cerutti, Claessens, \& Laeven, 2017). In addition, it became clear that simultaneously with the active reduction of systemic risks, the financial actors' shock-tolerance needs to be improved.

The fundamental goal of macroprudential policy is to moderate financial risks threatening with excessive systemic disorder, i.e. the financial intermediary system's disorder that causes significant damage to the entire economy. Thus, efforts must be made at the prevention of major financial crises, on the one hand, and at reducing the losses caused by any evolving financial crises to the real economy, on the other. In practice, this includes the following intermediate targets (Magyar Nemzeti Bank, 2016):

- prevention and moderation of excessive increase in lending and capital leverage

- prevention and reduction of excessive maturity mismatch and market liquidity shortage

- limiting the concentration of direct and indirect exposures

- mitigation of the adverse incentives increasing systemic risk, especially moral hazard

- reinforcement of the adaptability of the financial infrastructure

All this means that macroprudential actions should endeavour to achieve the following strategic goals:

(1) Encouragement of prudent risk assumption. Systemic financial risks increase and financial crises evolve primarily as a result of excessive risk assumption, and so their control and limitation is a priority task. As excessive risk assumption is in many cases caused by market frictions and failures, it is important to carefully manage these latter ones.

(2) Improvement of the shock-absorbing capacity. As a shock hitting the financial system may evolve into a financial crisis, it is important to make efforts at improving the shock resistance of the financial intermediary system as much as possible so that it can overcome financial stresses in the best possible condition. Thus hitches may be mitigated in the financial system, while the risk that they feed through to the real economy and multiple crisis effects can also be reduced. This presumes appropriate capital and liquidity reserves and a banking sector structure resistant to epidemic effects.

(3) A financial system sustainably supporting economic growth. Irrespective of its cyclical position, the financial system as a whole has to promote the functioning of the entire economy in the most sustainable manner.

In respect of household lending, the most important macro-prudential actions include debt cap rules - a wide-spread regulatory solution in Europe, and more specifically in Eastern and Central Europe, once highly exposed in the field of household lending. The debt cap rules applied in the majority of the countries include the loan-to-value indicator (LTV), giving the ratio of a loan to the collateral provided to secure it, and the indicator showing debtor repayment capacity. The latter group typically includes two kinds of indicators: (1) indicators specifying the ratio of repayment instalment to income (PTI), which cap monthly repayment instalments according to debtor incomes, and (2) loan-to-income (LTI) indicators, specifying the maximum loan amount that can be borrowed on the basis of debtor incomes.

Based on the 2018 data, among Central and Eastern European countries in the focus of this study, Hungary and Slovakia apply mandatory loan-to-value indicators and loan-to-income repayment instalment limits, while the other countries in the region (Czech Republic, Poland, Slovenia and Croatia) only give rec- 
ommendations or have mandatory regulations only in respect of the loan-to-value ratio, and provide recommendations for loan-to-income repayment instalment limits in addition to mandatory LTVs.

Several differences are identifiable in the regulatory environment used in the different countries. In Hungary regulation applies to a wide range of institutions, including credit institutions and non-bank lenders, thus reducing the opportunity to circumvent the regulation. In addition to Hungary, only Estonia and Slovakia have adopted requirements that regulate the prudent evidencing of incomes after taxes, the other countries with mandatory regulations leave the determination of creditable incomes to the banks. Differentiation according to risk dimensions, especially by denomination, is characteristic of several countries (Hungary, Romania). This means that foreign currency loans are subject to more stringent limits. Several states apply exceptions to the debt brake rules: the Czech Republic and Slovakia for less risky groups of borrowers, and Estonia and Lithuania provide an opportunity for the disbursement of loans above the maximum allowed LTV and LTI.

In Hungary, which can serve as a regional model in phasing-out household foreign currency loans, it was an emphatic question if a potential monetary policy normalization could cause a problem similar to the one related to foreign currency loans in the event of floating rates (as if interest rates rise in the case of forint loans with short interest rate periods, repayment instalments may increase over the short term, and this places customers under extra pressure). In this context the following structural differences should be highlighted:

- In case of foreign currency loans the exchange rate risk had an impact in both the payable amount of interest and the principal, and consequently, repayment instalments could rise faster and for a longer time.

- The interest rate risk involved in loans with shorter interest rate periods gradually decreases due to the regular principal repayment, i.e. loan amortization. Thus, over time, even if interest rates rise, they have less impact on repayment instalments.

- While on the part of households, practically no one benefitted from the exchange rate weakening in balance-sheet terms, as deposits were denominated in the domestic currency, the case is different if interest rates rise, as interest incomes may increase for households in a net saving position.

- The ratio of loans with short interest fixation periods in new disbursements is on the decline, and their ratio to the total loan portfolio is lower than that of foreign currency loans before the crisis.

- In contrast to the previous period, the regulatory authority's activity has increased considerably and the central bank uses several instruments to promote the spread of loans with longer interest fixation periods, including the MNB's mortgage bond purchase programme in 2018, the interest rate swap (IRS) tenders, the targeted recommendations of the central bank, and the adoption of the mortgage financing adequacy ratio(Magyar Nemzeti Bank, 2018).

Prior to the crisis, beside of the denomination of loans it was also a challenge that households assumed loans far beyond their income positions. Today this is limited by debt cap rules. The MNB was among the first in Europe to adopt mandatory and comprehensive debt cap rules (see: Fáykiss, Palicz, Szakács, \& Zsigó, 2018). The rules that entered into force on January 2015 limit the "stretch" of both debtor incomes and collateral values. The regulation requires that the amount of newly granted household loans may not exceed 80 per cent of the collateral (LTV), and as a rule of thumb, a debtor's aggregate repayment instalments may only reach 50 per cent of his regular and legal income (LTI). In order to offset the various risks, the Hungarian regulation sets tighter limits in the event of foreign currency loans and more lenient ones for borrowers with higher incomes.

With due consideration to financial stability and consumer protection, in June 2017 the MNB adopted the Qualified Consumer-Friendly Housing Loan rating scheme. The rated loans have longer interest fixation periods, typically between 5 and 10 years, are favourably priced and standardized, and thus they provide more efficient protection against interest rate risk than loans with shorter interest fixation periods. The extensive spread of these products may contribute to further increase in the ratio of loans concluded for longer interest fixation periods.

\section{Conclusions}

In Hungary the level of new loan placements has 
shown fast expansion since the beginning of 2013 which was the less active year post-GFC from the point of view of lending. By $2017 \mathrm{H1}$, it had returned to the levels recorded in early 2006 . The fastest increase was recorded for household mortgage loans, which increased from HUF 85 billion in early 2016 to HUF 171 billion in 2017 Q2. In 2018 household credit grew by HUF 424 billion over the whole year on account of credit transactions, meaning an increase of 7.3 per cent YoY. Housing loan disbursement amounted to HUF 850 billion, reaching the 2008 level in nominal terms (Magyar Nemzeti Bank, 2019). Nevertheless, in contrast to the period before the crisis, the debt cap rules in the present credit cycle prevent households becoming over-indebted, so even the fast increase in lending has not run the households into significant indebtedness (Fáykiss et al., 2018).

The disbursed home loans are denominated in forint, and in comparison to the 19-20 years maturity generally contracted before the crisis, their terms shortened (app. 16 years), at a considerably lower LTV, and a significant ratio of the individual transactions are not concentrated close to the LTI limits. One fifth of the loans are disbursed to more indebted customers with 40-60 per cent LTI, however, the ratio recorded in 2015 was still exceeded by altogether 5 percentage points only. Higher increase in real wages may decelerate or even halt further increase. In comparison to the years preceding the crisis, the risk involved in both home and consumer loans is far lower (typically due to denomination in forint, lower LTV levels etc.). For this reason, fast increase in lending serves the purpose of achieving equilibrium lending and it is not to be considered as excessive. The probability of future debt problems related to housing market developments is decreased by the facts that no more than half of the housing transactions include borrowing, and that real property collateral are provided for home loans at low, although slowly increasing, charge levels. In 2018 Q4 more than 90 per cent of the new housing loans were disbursed with an interest rate fixation of over one year, while the share of loans fixed for over 5 years was almost two-third (Magyar Nemzeti Bank, 2019).

In June 2018 the MNB amended the parameters of the debt cap rules, and the new regulation favours loans with longer interest fixation periods. Concerning
LTI rules, higher incomes allow the assumption of relatively higher repayment instalments. In view of the increase seen in nominal and real wages during the past few years, the decree allows the assumption of higher repayment instalments for those earning HUF 500,000 instead of the prior income limit of HUF 400,000. In a forward-looking perspective it will be of particular importance to closely monitor and assess the lending dynamics, essentially concerning the impact of the evolution of the macroeconomic environment, especially property prices and wages, and the contribution of the new child support and interest-subsidised loans provided under the family housing benefit scheme and the family protection action plan of the government, offered to young married couples (preferential housing 'csok' loans, baby expecting support, optional reduction of the mortgage debts of families with three or more children).

\section{References}

Akinci, O., \& Olmstead-Rumsey, J. (2018). How effective are macroprudential policies? An empirical investigation. Journal of Financial Intermediation, 33, 33-57.

Basso, H., Calvo-Gonzalez, O., \& Jurgilas, M. (2007). Financial dollarization - the role of banks and interest rates. European Central Bank Working Paper Series, 748. https://www.ecb.europa.eu/pub/pdf/ scpwps/ecbwp748.pdf

Basso, H. S., Calvo-Gonzalez, O., \& Jurgilas, M. (2011). Financial dollarization: The role of foreign-owned banks and interest rates. Journal of Banking \& Finance, 35(4), 794-806.

Beer, C., Ongena, S., \& Peter, M. (2010). Borrowing in foreign currency: Austrian households as carry traders. Journal of Banking \& Finance, 34(9), 2198-2211.

Bethlendi, A. (2011). Policy measures and failures on foreign currency household lending in Central and Eastern Europe. Acta Oeconomica, 61(2), 193223.

Bethlendi, A. (2015). Bad product development results in systemic market failure-Foreign currency mortgage loans to Hungarian households. Financial and Economic Review, 14(1), 5-30.

Boar, C., Gambacorta, L., Lombardo, G., \& Pereira da Silva, L. (2017). What are the effects of macroprudential policies on macroeconomic performance? BIS Quarterly Review September 2017, 71-88. https://ssrn.com/abstract=3042014

Brown, M., \& De Haas, R. (2012). Foreign banks and foreign currency lending in emerging Eu- 
rope. Economic Policy, 27(69), 57-98.

Brown, M., De Haas, R., \& Sokolov, V. (2013). Regional inflation and financial dollarization. CentER Discussion Paper 2013-073. https://research. tilburguniversity.edu/files/1557688/2013-073.pdf

Brown, M., \& Stix, H. (2015). The euroization of bank deposits in Eastern Europe. Economic Policy, 30(81), 95-139.

Carreras, O., Davis, E., \& Piggott, R. (2016). Macroprudential tools, transmission and modelling. Firstrun Deliverable 4.7, Horizon 2020 and NIESR Discussion Paper 470. https://ssrn.com/ abstract $=2967270$

Cerutti, E., Claessens, S., \& Laeven, L. (2017). The use and effectiveness of macroprudential policies: New evidence. Journal of Financial Stability, 28, 203-224.. https://doi. org/10.1016/j. jfs.2015.10.004

Csajbók, A., Hudecz, A., \& Tamási, B. (2010): Foreign currency borrowing of households in new EU member states. MNB Occasional Papers 87.

Csávás, C., \& Csom-Bíró, G. (2017): Indicators used for the assessment of the reserve adequacy of emerging and developing countries - International trends in the mirror of theories. Financial and Economic Review, 16(1), 5-45.

Cuaresma, J. C., Fidrmuc, J., \& Hake, M. (2011). Determinants of foreign currency loans in CESEE countries: A meta-analysis. Focus on European Economic Integration, (4), 69-87.

Dancsik, B., Fábián, G., Fellner, Z., Horváth, G., Lang, P., Nagy, G., Oláh, Z., Winkler, S. (2015). Comprehensive analysis of the nonperforming household mortgage portfolio using micro-level data. MNB Occasional Papers Special Issue, 2015. https:// www.mnb.hu/letoltes/mnb-occasional-papersspecial-issue.pdf

De Nicoló, G., Honohan, P., \& Ize, A. (2005). Dollarization of bank deposits: Causes and consequences. Journal of Banking \& Finance, 29(7), 16971727.

Eichengreen, B., \& Hausmann, R. (2010). Other people's money: debt denomination and financial instability in emerging market economies. University of Chicago Press.

Fáykiss, P., Palicz, A., Szakács, J., \& Zsigó, M. (2018). Experiences of debt cap regulations in Hungarian retail lending. Financial and Economic Review, 17(1), 34-61.

Geng, M. N., Scutaru, T., \& Wiegand, M. J. (2018). Carry trade vs. deposit-driven Euroization. International Monetary Fund.

Ize, A. (2005). Financial dollarization equilibria: A framework for policy analysis. IMF Working $\mathrm{Pa}$ per, 2005/186.

Jackowicz, K., Kowalewski, O., \& Kozłowski, Ł. (2011). The short and long term performance persistence in the Central European banking industry. Cont- emporary Economics, 5(4), 18-31.

Jeanne, O. D. (2003). Why do emerging economies borrow in foreign currency? IMF Working Paper, 2003/177.

Kecskés, A. (2015). Inside and outside the province of jurisprudence. Rechtstheorie, 46(4), 465-479.

Submitter, F., Kolozsi, P. P., Banai, A., \& Vonnak, B. (2015). Phasing out household foreign currency loans: schedule and framework. Financial and Economic Review, 14(3), 60-87.

Lentner, C., Kolozsi, P. P., \& Tóth, G. (2010). A magyar válságkezelés sajátosságai és ellentmondásai [The peculiarities and contradictions of Hungarian crisis management]. EU Working Papers, 13(1), 3-17.

Magyar Nemzeti Bank (2016). Stability today - Stability tomorrow. Macroprudential strategy of the Magyar Nemzeti Bank. https://www.mnb.hu/letoltes/ mnb-macroprudential-strategy-of-the-magyarnemzeti-bank-2016.pdf

Magyar Nemzeti Bank (2018). Annual report. 2018 Business report and financial statements of the Magyar Nemzeti Bank. https://www.mnb.hu/ letoltes/mnb-annual-report-2018.pdf

Magyar Nemzeti Bank (2019). Trends in lending. March 2019. https://www.mnb.hu/letoltes/ hitelezesi-folyamatok-2019-marcius-en.pdf

Matolcsy, G. (2015). Economic balance and growth. Kairosz Kiadó.

Matolcsy, G., \& Palotai, D. (2018). The Hungarian model: Hungarian crisis management in view of the mediterranean way. Financial and Economic Review, 17(2), 5-42. Matolcsy, G., \& Palotai, D. (2018). The Hungarian Model: Hungarian Crisis Management in View of the Mediterranen Way. Financial and Economic Review, 2018. Vol. 17. No. 2. pp. 5-42.

Ranciere, R., Tornell, A., \& Vamvakidis, A. (2010). Currency mismatch, systemic risk and growth in emerging Europe. Economic Policy, 25, 597-658

Schneider, M., \& Tornell, A. (2004). Balance sheet effects, bailout guarantees and financial crises. The Review of Economic Studies, 71(3), 883913.

Zéman, Z., Hegedûs, S., \& Molnár, P. (2018). Analysis of the Creditworthiness of Local Government-owned Companies with a Credit Scoring Method. Public Finance Quarterly, 63(2), 176195.

Zettelmeyer, J., Nagy, P. M., \& Jeffrey, S. (2010). Addressing private sector currency mismatches in emerging Europe. European Bank for Reconstruction and Development. 